\title{
Quality of Coconut Oil using Fruit of Dwarf Coconut
}

\author{
Steivie Karouw ${ }^{1}$, Chandra Indrawanto ${ }^{2}$ and Hengky Novarianto ${ }^{3}$
}

\begin{abstract}
The purpose of this research was to study processing of coconut oil which focused on evaluation of the quality of oil by using fruit of several Dwarf coconut as raw materials. The varieties used were Salak Green Dwarf (SGD), Raja Brown Dwarf (RBD) and Bali Yellow Dwarf (BYD). The oil was extracted through the wet process by heating technique. The coconut oil volume was measured and evaluated for its fatty acids profile, free fatty acid contents, moisture content, color, smell and taste. The by-products such as coconut residue and blondo were measured, too. The results showed that processing of oil from 200 Dwarf nuts produced 7.1-8.4 L. The highest volume of oil $(8.4 \mathrm{~L})$ was resulted from SGD. The oil was generally having high medium chain fatty acid around 58.50-62.32\% including lauric acid at 46.82-48.46\%. The oil made from fruits of SGD contained the highest lauric acid around $48.46 \%$, followed by RBD and BYD reaching $48.06 \%$ and $46.82 \%$, respectively. It had a good smell, and fatty acid and moisture content were in accord with Indonesian National Standard. The coconut oil processed using the fruit of the SGD and RBD has a clear white color, while the BYD having clear yellow in color, like corn oil.
\end{abstract}

Keywords: coconut oil, Dwarf coconut, lauric acid

\section{Introduction}

Dwarf coconut fruits are extensively used in the form of a tender coconut (fruit age 8 months). Commonly, it is consumed as fresh coconut, and provides raw materials for making klapertaart and coconut jam. The mature nuts (11-12 months of fruit), both of fresh nuts or copra form have no economic value. The high content of galactomanan and phospholipids in the meat of fruit of Dwarf coconut provides a springy texture, so it is not suitable as a raw material in a coconut industry producing oil through the dry process. These two chemical components function as a stabilizer (Prajapati et al., 2013) causing high stability of milk emulsion and could not be separated through centrifugation technique (Karouw et al., 2014a). The wet heating technique could be developed to extract the oil from the milk emulsion which was prepared from Dwarf coconut kernel.

\footnotetext{
${ }^{1}$ Indonesian Palmae Research Institute (IPRI), Jl. Raya Mapanget, PO BOX 1004, Manado, North Sulawesi, Indonesia. Email: steivie_karouw@yahoo.com

${ }^{2}$ Badan Penelitian dan Pengembangan Pertanian - Balitbangtan, Jl. Ragunan 29, Pasar Minggu, Jakarta Selatan 12540, Indonesia. Email: chandraindrawanto@litbang.deptan.go.id

${ }^{3}$ Coconut Breeders, Indonesian Palm Research Institute (IPRI), P.O. Box 1004, Manado 95001, North Sulawesi Province, Indonesia. Email: hengkynovarianto@yahoo.com
} 
Coconut oil can be produced through a wet or dry extraction. In dry extraction, coconut oil is produced using raw materials of copra (Lay and Karouw, 2007) or partially desiccated coconut. The dry copra method is more appropriate to be carried out on an industrial scale (Marina et al., 2009a). Through the wet method itself, many ways of processing of coconut oil have been described. The oil could be obtained through evaporation by heating (Rindengan and Karouw, 2002), fermentation (Rindengan et al, 2004) or centrifugation of coconut cream (Karouw et al, 2014). The wet process appears more desirable being free from usage of chemical solvents, thus more environmental friendly than the dry copra method which uses solvent to extract the oil. In general, the coconut oil producing by industry or at the farmers' level are using fruit from Tall palms. To our knowledge, in the literature, there is no more information regarding the processing of coconut oil using the fruits of Dwarf coconut as raw material.

The coconut oil which is produced by wet method can be used as a healthy cooking oil, because it has high percentage of medium chain fatty acids/MCFAs (58.5-62.32\%). The MCFAs in coconut oil are caprylic acid (C8: 0), capric acid (C10: 0) and lauric acid (C12: 0$)$. which in the coconut oil, amounted to $46.64-48.03 \%$ (Marina et al., 2009b). Medium chain fatty acids, especially lauric acid are very good for health, being antiviral, antibacterial and antiprotozoal (Enig, 1999).

Processing of oil by using raw material from the Dwarf has an advantage due to the trees being shorter at any age compared to the Tall. Therefore, the power climber problem could be avoided during harvesting. Recently, much attention have been given to methods of picking the fruit, due to difficulties of finding climbers. This condition directly increased the harvesting cost leading to the choice of trees which are shorter, such as Hybrid (D X T) and Dwarf being chosen.

Processing of coconut oil through the wet method is much simpler compared to others techniques. This method can be conducted at home or on a farmer's scale. A total of 7.1 to 8.4
$\mathrm{L}$ of coconut oil can be produced from the processing of 200 Dwarf nuts. It is estimated that from an area of 1 ha approximately 700-820 L coconut oil can be obtained. This result is obtained by assuming the area of 1 ha can be planted with 200 trees with production ranging from 17,500-20,500 nut/year. It is estimated that at the selling price of $\mathrm{Rp} 20,000 / \mathrm{L}$, then the income of $\mathrm{Rp} 14$ million-16.4 million (USD 1,166-1,366) per hectare.

The purpose of this research is to study processing of coconut oil and evaluating the quality of oil by using the fruit of several Dwarf palms as raw material.

\section{Materials and methods}

\section{Materials}

The coconut fruits (11-12 months) were harvested from 3 varieties of Dwarf coconut namely Bali Yellow Dwarf (BYD), Raja Brown Dwarf (RBD) and Salak Green Dwarf (SGD). Salak Green Dwarf (SGD) was cultivated at Kima Atas experimental garden, meanwhile both of BYD and RBD were cultivated at Mapanget experimental garden, North Sulawesi Province, Indonesia. The type of varieties using for raw material are described on Table 1.

\section{Processing of Coconut Oil}

The oil from coconut fruit were extracted by wet process using heating technique. It was a modification of the processing of coconut oil with gradual heating method performed by Lay and Rindengan (1989). The processing of oil is as follows: the fresh mature nuts are dehusked, cut and deshelled. The meat then is shredded using grated machines. Tap water is added into the grated kernel in the ratio of 1: $1(\mathrm{w} / \mathrm{v})$, then squeezed using expeller to get milk. Coconut milk is poured in a transparent plastic container fitted taps on the bottom. Coconut milk is then allowed to stand for $\pm 1-2$ hours, so it would form a layer on the bottom (skim) and cream on top. Skim and cream is separated by opening tap on the bottom of the container to remove the skim. The cream is then put in a transparent plastic container and allowed to stand for 12-14 hours, so it will form two layers, namely the oilrich layer on the top and non oil layer on the 
Table 1. Dwarf coconut varieties which were used

\begin{tabular}{lccc}
\hline \multicolumn{1}{c}{ Description } & BYD & RBD & SGD \\
\hline Age of first flowering (years) & 3 & 3 & 2 \\
Age of first harvesting (years) & 4 & 4 & 3 \\
Number of bunches/palm/year & 15.15 & 12.91 & 12.96 \\
Number of nuts/palm/year & 99.20 & 78.75 & 109.51 \\
Number of nuts/ha/year & 17,676 & 14,175 & 19,711 \\
\hline
\end{tabular}

Sources: Anonim (2014)

Table 2. Volume of oil and its by products processed from 200 nuts

\begin{tabular}{lcccc}
\hline \multicolumn{1}{c}{ Varieties } & $\begin{array}{c}\text { Weight of meat } \\
(\mathrm{kg})\end{array}$ & $\begin{array}{c}\text { Volume of oil } \\
(\mathrm{L})\end{array}$ & 7.1 & \multicolumn{2}{c}{ Weight of by products } \\
\cline { 4 - 5 } & 57.5 & & 3.5 & Blondo $(\mathrm{kg})$ \\
\hline $\begin{array}{l}\text { Bali Yellow Dwarf } \\
\text { (BYD) }\end{array}$ & 56.0 & 8.3 & 4.7 & 36.7 \\
$\begin{array}{l}\text { Raja Brown Dwarf } \\
\text { (RBD) }\end{array}$ & 49.0 & 8.4 & 3.2 & 29.3 \\
$\begin{array}{l}\text { Salak Green Dwarf } \\
\text { (SGD) }\end{array}$ & & & & \\
\hline
\end{tabular}

Table 3. Fatty acid composition of oil from Dwarf compared to Mapanget Tall

\begin{tabular}{lcccc}
\hline Fatty acids & \multicolumn{4}{c}{ Coconut varieties/\% of fatty acid } \\
\cline { 2 - 5 } & BYD & RBD & SGD & MTT $\left.^{*}\right)$ \\
\hline Caprilic (C8:0) & 6.52 & 7.20 & 7.59 & 7.41 \\
Capric (C10:0) & 5.16 & 6.12 & 6.27 & 6.28 \\
Lauric (C12:0) & 46.82 & 48.06 & 48.46 & 48.24 \\
Miristic (C14:0) & 19.45 & 18.21 & 18.88 & 19.26 \\
Palmitic (C16:0) & 9.70 & 9.07 & 9.22 & 9.29 \\
Stearic (C18:0) & 6.17 & 4.85 & 4.85 & 2.44 \\
Oleic (C18:1) & 0.81 & 2.22 & 0.46 & 5.83 \\
Linoleic (C18:2) & 5.37 & 4.27 & 4.27 & 1.26 \\
Total of MCFA & 58.50 & 61.38 & 62.32 & 61.93 \\
\hline
\end{tabular}

Sources: ${ }^{*}$ Karouw et al. (2013)

$\mathrm{BYD}=$ Bali Yellow Dwarf; RBD= Raja Brown Dwarf; SGD= Salak Green Dwarf; MTT= Mapanget Tall Coconut 
bottom. Further oil-rich layer was poured into a frying pan. The heating is done until it becomes light brown blondo. The resulting oil is separated from blondo, cooled and then filtered using a sterile cotton. Flowchart of coconut oil processing is presented in Figure 1.

\section{Evaluation of Coconut Oil Quality}

The volume of oil produced was measured by using a volumetric flask. Its by products such as proteinaceous matter (blondo) and coconut residue were also calculated. The extracted oil was then analyzed for its fatty acid profile using Gas Chromatography. The GC used for analizing was a Shimadzu-GC-9AM equipped with CPSIL-88 column (30m x 0,30 $\mathrm{mm}$ id) and flame ionization detector (FID). The injector and detector temperature were $230^{\circ} \mathrm{C}$, while column temperature was previously held at $120^{\circ} \mathrm{C}$, then programmed to $200^{\circ} \mathrm{C}$ at $8^{\circ} \mathrm{C} / \mathrm{min}$. Nitrogen was used as a gas carrier. The oils were also evaluated for its quality such as free fatty acids (titration method) and moisture content through thermogravimetric method (AOAC, 1990), and color, smell and taste by organoleptic evaluation.

\section{Result and discussion}

\section{Oil and its by products}

The processing of 200 Dwarf nuts produced 7.1-8.4 $\mathrm{L}$ of oil (Table 2). The highest volume of oil $(8.4 \mathrm{~L})$ was resulted from SGD, in contrast it having the lowest amount of blondo and residue compared to BYD and RBD.

The major component in blondo and coconut residue are protein and carbohydrate. Coconut residue contained protein and carbohydrate of $12.1 \%$ and $70.3 \%$, respectively (Trinidad et al., 2006), meanwhile protein content in blondo was $46.08 \%$ (Karouw, 2008). The protein component affected the stability of coconut milk, due to its capability to act as as emulsifier (Onsaard et al., 2005; Onsaard et al., 2006). The coconut milk emulsion is more stable at a high percentage of oil which is then more difficult to extract. It was proven by the data shown on Table 3, that oil in the kernel of SGD is extracted more completely compared to BYD and RBD. Novarianto et al. (1997) reported that protein content in meat of SGD is around $2.60 \%$, whereas RBD and BYD were $3.32 \%$ and $3.27 \%$, respectively. According to the results shown in Table 2, we can calculate the yield of oil from each Dwarf variety. The yield of oil extracted from SGD $(0.17 \%)$ is higher compared to RBD and BYD which are around $0.12 \%$ and $0.15 \%$, respectively.

The Salak Green Dwarf (SGD) is an example of coconut germplasm in South Kalimantan in the 1980s (Luntungan et al., 2014). The specific characteristics of fruit of SGD are as follows: rounded shape of fruit, small fruit size, and color green fruit (Novarianto et al., 1997). This variety grows well in lowland up to $300 \mathrm{~m}$ above sea level and its development in dry land areas wet climate with rainfall of $<2,500 \mathrm{~mm} /$ year (Luntungan et al., 2014).

Based on the results, in processing of cooking oil, the fruits of SGD obtained higher yield of oil compared to fruits of RBD and BYD. Based on these advantages, the SGD can be recommended as the most excellent raw materials for oil extraction among Dwarf varieties.

\section{Fatty acid composition of Dwarf coconut oil}

The oil contains Medium Chain Fatty Acids (MCFAs) ranging from 58.50 to $62.32 \%$. The fatty acids profile of the oil compares to oil of Mapanget Tall (MTT) as shown in Table 3. Lauric acid is a fatty acid with the highest proportion. Oil from Salak Dwarf coconut kernel contains ALRM slightly higher than that used coconut kernel of Mapanget Tall. The oil extracted from coconut Dwarf varieties contain fatty acids similar to Mapanget Tall except that the stearic acid of the Dwarf is noticeably higher, and oleic acid is lower than in Mapanget Tall.

The fatty acids profile was similar to the earlier report by Nevin and Rajamohan (2006) who reported that oil from Kerala, India contained $45.51 \%$ of lauric oil. The results are also in line with Bhatnagar et al. (2009) who reported coconut oil made in Mysore India having lauric acid of $49.61 \%$, capric and caprilic acids of 4.8 and $5.8 \%$, respectively. Marina et al. (2009b) reported that commercial coconut oil produced both in Malaysia and Indonesia 


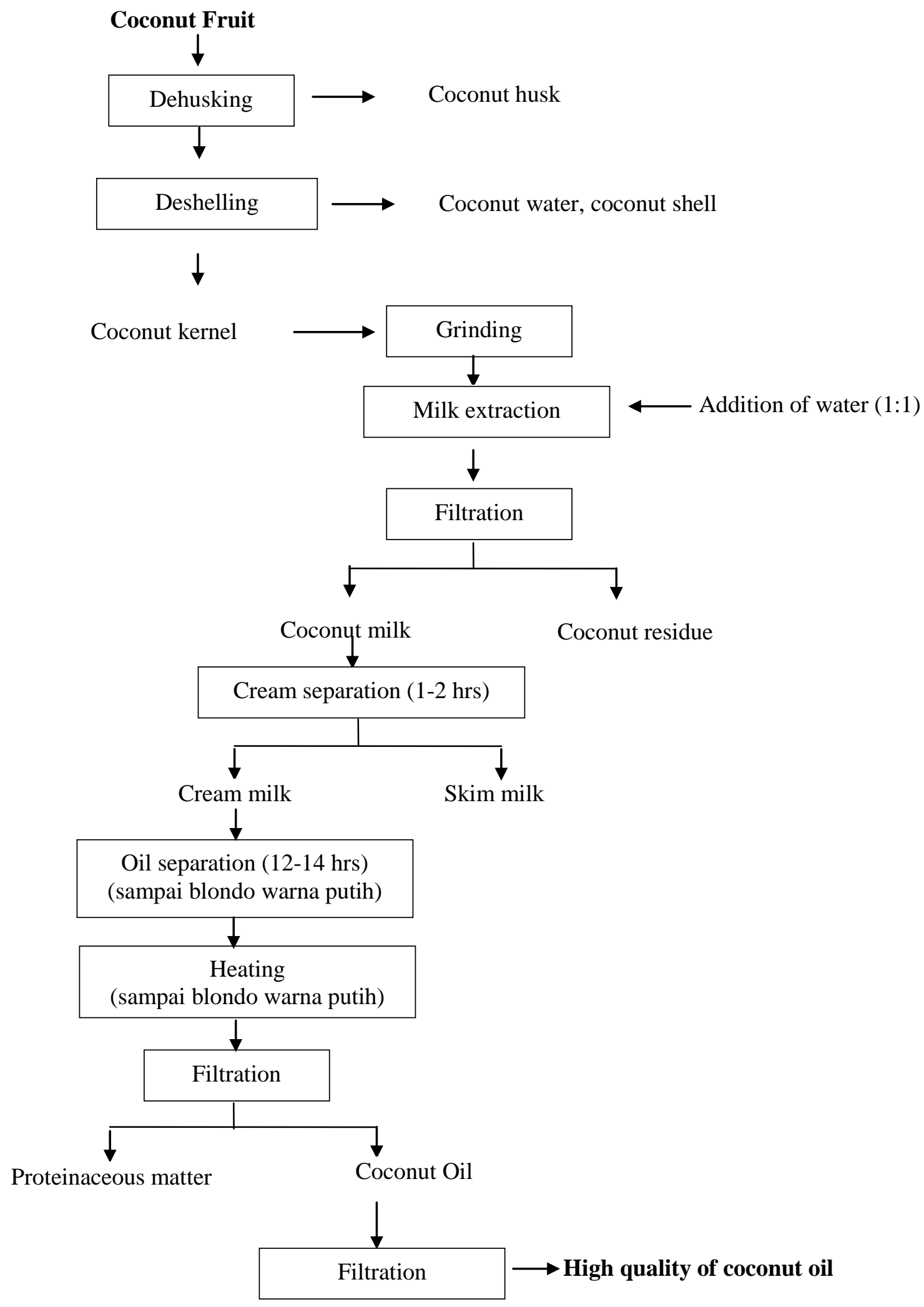

Figure 1. Processing of Coconut Oil using Fruits of Dwarf Coconut 
Table 4. Comparison of quality of oil made from Dwarf through different methods

\begin{tabular}{|c|c|c|c|c|c|}
\hline Parameter & $\begin{array}{l}\text { White copra } \\
\text { oil }^{\text {a) }}\end{array}$ & $\begin{array}{c}\text { Fermented } \\
\text { oil }^{\text {b) }}\end{array}$ & $\begin{array}{c}\text { Centrifuged } \\
\text { oil }^{\mathrm{c})}\end{array}$ & $\begin{array}{c}\text { Dwarf } \\
\text { coconut oil }\end{array}$ & $\begin{array}{c}\text { Indonesian } \\
\text { National } \\
\text { Standard }\end{array}$ \\
\hline Moisture (\%) & $0.13-0.18$ & $0.10-0.15$ & 0.16 & $0.10-0.12$ & $0.1-0.5$ \\
\hline Free fatty acid (\%) & $0.43-0.45$ & $0.19-0.24$ & 0.11 & $0.14-0.16$ & Max. 0.6 \\
\hline Color & $\begin{array}{l}\text { Clear white to } \\
\text { white yellow }\end{array}$ & Clear white & Clear white & $\begin{array}{l}\text { Clear white, } \\
\text { clear yellow }\end{array}$ & $\begin{array}{c}\text { Clear white, } \\
\text { Yellow }\end{array}$ \\
\hline Smell & $\begin{array}{c}\text { Free from } \\
\text { foreign smell }\end{array}$ & Coconut smell & Coconut smell & Coconut Smell & Normal \\
\hline Taste & A few rancid & Not rancid & Not rancid & Not rancid & Normal \\
\hline
\end{tabular}

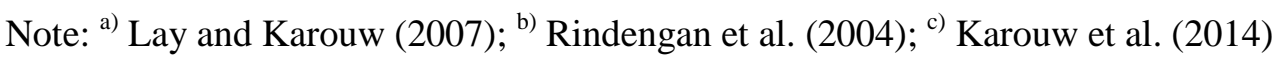

contained lauric oil at 46.64-48.03\%, and miristic acid (C14) at 16.23-18.90\%. Thus, we consider that coconut oil which was produced through the wet process by a heating technique, from Dwarf has fatty acids similar to Talls.

\section{Quality of coconut oil made from fruits of Dwarf Coconut}

Coconut oil from the Dwarf separated by the heating method has the variables of moisture, free fatty acid, smell, taste and color according to the Indonesian National Standard. The results are presented in Table 4. The colour of coconut oil is different depending on the raw materials used. The oil from RBD and SGD has a clear white color; meanwhile the oil of BYD has a yellow color like corn oil. We consider that, the kernel of BYD contains carotene which has the ability to inhibit oxidation of the oil (Chen and Liu, 1998).

Based on the data in Table 4, coconut oil produced by different processing methods has quality in line with the Indonesian National Standard, except for the taste of white copra oil; white copra oil has a slight rancid flavor. It's free fatty acid levels were higher than in oil extracted through fermentation, centrifuging and heating. The centrifuged oil noticeably had lower free fatty acid. The oil which is made without high heat, deteriorates more readily by hydrolysis reaction which is indicated by a rancid flavor. This is due to the formation of methyl ketones as a result of degradation by microorganisms (Villarino et al., 2007). Rancidity is also caused by the oxidation reaction (Martin et al., 2010). Rancid odor can be detected by taste panelists when the VCO has a peroxide value $\geq 1 \mathrm{meq} / \mathrm{kg}$ (Rukmini and Raharjo, 2010).

According to the results of this study, therefore, we consider that the oil extracted from the fruit of the Dwarf coconut is of high quality. The key variables of moisture content, free fatty acid, smell, taste and color all comply with the Indonesian National Standard.

\section{Conclusion}

Processing 200 nuts of Dwarf coconut yielded 7.1-8.4 L of oil (8.4 L) from SGD.

Medium chain fatty acid was around $58.50-62.32 \%$ with lauric around $46.82-48.46 \%$. Smell, free fatty acid and moisture content complied with the Indonesian National Standard.

The advantage of processing coconut oil from Dwarf nuts compared to Tall is of lower cost, due to reduced need for climbers to harvest the fruit.

\section{References}

Anonim. 2002. Nutritional Value of Coconut Kernel. The Cocommunity. XXXII (1) 15 Januari 2002. hal. 11-12. 
Anonim. 2014. Kelapa Genjah Unggul. Poster Balai Penelitian Tanaman Palma, Manado.

Bhatnagar., A.S., Prasant Kumar, P.K., Hemavathy, J. and Kopala, A.G.G. 2009. Fatty acid composition, oxidative stability and radical scavenging activity of vegetable oil blends with coconut oil. Journal of the American Oil Chemists' Society 86: 991-999.

Chen, B.H. and M.H. Liu. 1998. Relationship between chlorophyll a and $\beta$-caroten in a lipid-containing model system during illumination. Journal of American Oil Chemists' Society 74: 1115-1119.

Enig, M. E. 1999. “Coconut: In Support of Good Health in the $21^{\text {st }}$ Century", Paper presented on APPC'S XXXVI Session and $30^{\text {th }}$ Anniversary in Pohnpei, Federated States of Micronesia.

Karouw, S., Suparmo, P. Hastuti. and T. Utami. 2013. Sintesis ester metil rantai medium dari minyak kelapa dengan cara metanolisis kimiawi. Agritech 33(2): 182188.

Karouw, S., C. Indrawanto, and M.L. Kapu'Allo. 2014. Karakteristik virgin coconut oil dengan metode sentrifugasi. Buletin Palma 15(2): 128-133.

Karouw, S. and B. Santosa. 2014. Minyak kelapa: sumber asam lemak rantai medium. Prosiding Konferensi Nasional Kelapa VIII. Jambi, 21-22 Mei 2014.

Lay, A. and B. Rindengan. 1989. Pengolahan minyak kelapa dengan pemanasan bertahap. Terbitan Khusus No. 15/VIII/1989. Balitka Manado. HIm 89-90.

Lay, A., and S. Karouw. 2007. Pengolahan minyak kelapa dari kopra putih dengan metode kering. Prosiding Konferensi Nasional Kelapa VI. Gorontalo 16-18 Mei 2006. Hal 249-256.

List, G.R., T. Wang, and V.K.S. Shukla. 2005. Storage, Handling and Transport of Oils and Fats dalam Bailey's Industrial Oil and Fat Products, $6^{\text {th }}$ ed., Vol. 5. John Wiley \&
Sons, Inc., Hoboken, New Jersey.

Luntungan, H.T., H. Tampake, E. Wardiana, E. Randriani, and H. Novarianto. 2014. Kelapa Genjah varietas Salak. Web Puslitbun. Diunggah 26 Agustus 2014.

Martin, D., G. Regiero and F.J. Senorans. 2010. Oxidative stability of structured lipids. Europe Food Research Technology 231:635-653.

Marina, A.M., Y.B. Che Man. and I. Amin. 2009a. Virgin coconut oil: emerging functional food oil. Trends in Food Science and Technology 20: 481-487.

Marina, A.M., Y.B. Che Man and S.A.H. Nazimah. 2009b. Chemical properties of virgin coconut oil. Journal of the American Oil Chemists' Society 86: 301-307.

Nevin, K.G. and Rajamohan, T. 2006. Virgin coconut oil supplemented diet increases the antioxidant status in rats. Food Chemistry 99: 260-266.

Novarianto, H., Miftahorrachman and J. Kumaunang. 1997. Peluang bisnis pengembangan benih unggul kelapa. Prosiding Temu Usaha Perkelapaan Nasional, Manado 6-8 Januari 1997. Hal 86-108.

Onsaard, E., M. Vittayanont, S. Srigam and D.J. McClements. 2005. Properties and stability of oil-in-water emulsions stabilized by coconut skim milk proteins. J. Agricultural Food Chemistry 53(14): 5747-5753.

Onsaard, E., M. Vittayanont, S. Srigam and D.J. McClements. 2006. Comparison of properties of oil-in-water emulsions stabilized by coconut cream proteins with those stabilized by whey protein isolates. Food Research International 39: 78-86.

Prajapati, V.D., G.K. Jani., N.G. Moradiya, N.P. Randeria, B.J. Nagar, N.N. Naikwadi and B.C. Variya. 2013. Galactomannan: A versatile biodegradable seed polysaccharide. International Journal of Biological Macromolecules 60: 83-92. 
Rindengan, B., and S. Karouw. 2002. Peluang pengolahan minyak kelapa murni. Prosiding Konferensi Nasional Kelapa V. Tembilahan, Riau 21-21 Okotober 2002. Hlm 146-153.

Rindengan, B. S. Karouw, R.T.P. Hutapea, and A. Lay. 2004. Melirik nilai tambah minyak kelapa murni. Makalah disampaikan pada Temu Bisnis dalam rangka Simposium IV Hasil Penelitian Tanaman Perkebunan, Bogor, 28-30 September 2004.

Rindengan, B., S. Karouw, and P.M. Passang. 2004. Pengaruh konsentrasi starter Saccharomyces cerevisiae and lama fermentasi terhadap rendemen and mutu minyak kelapa. Jurnal Penelitian Tanaman Industri 10(3): 106-111.

Rindengan, B., S. Karouw, and R.T.P. Hutapea. 2009. Minyak kelapa murni (virgin coconut oil): pengolahan, pemanfaatan and peluang pengembangannya. Monograf Pasca Panen Kelapa. Hal 9-19.

Rukmini, A. and S. Raharjo. 2010. Pattern of peroxide value changes in virgin coconut oil (VCO) due to photo-oxidation sensitized by chlorophyll. Journal of the American Oil Chemists' Society 87: 14071412.

Trinidad, T.P., A.C. Mallilin, D.H. Valdez, A.S. Loyola, F.C.A. Mercado, J.C. Castillo, R.R. Encabo, D.B. Masa, A.S. Maglaya and M.T. Chua. 2006. Dietary fiber from coconut flour: A functional food. Innovative Food Science and Emerging Technologies 7: 309-317

Villarino, B., L.M. Dy and M.C.C. Lizada. 2007. Descriptive sensory evaluation of virgin coconut oil and refined, bleached and deodorized coconut oil. LWT Food Science and Technology 40: 193-199. 